\title{
P 388
}

\section{OHMSにおける産業看護職の役割}

○松井 三穂·荒木 郁乃·中木 利枝子·久喜 直子·田中 志津香·鈴木 英孝·森 晃爾 (エクソンモービルビジネスサービス 医務·産業衛生)

\section{【はじめに】}

日本におけるエクソンモ一ビルグループは 2000 年 7 月、米国 $\mathrm{E}$ 社・M社の国内関連会社6社が合併・ 業務統合したグループとして発足した。現在、管理業 務を行うエクソンモ一ビルビジネスサービス(有) (以 下 EMBS)、営業部門のエクソンモービルマーケテ イングサービス(有)、石油精製等·物流部門の東燃 ゼネラル石油(株)の3社により運営されている。

産業保健サービスはEMBSの一部門である医務・ 産業衛生(Medicine\&OccupationalHealth:MOH) が担当している。この組織は、健康管理を行う産業 医 $(\mathrm{OP})$-産業看護職 $(\mathrm{OHN})$ と、作業環境対策など衛 生管理を行うインダストリアルハイジニスト(IH)の産 業保健専門職3職により構成され、全ての事業所へ のサービスを提供している。

【OHMSとは】

Exxonmobil では、安全·衛生·環境に対する配慮 を操業上の最優先事項と考え、世界共通のガイドラ インによるマネージメントシステム(Operations Integrity MS:OIMS)を構築し実施している。産業 保健活動もOIMSの一部として、リスクアセスメント 及び職務適性に関する活動を産業保健マネージメン トシステム(以下 OHMS)として構築し、健康に関する 方針や関連事項を遵守するため運用している。

OHMS は主に(1)職務上の健康障害防止対策(2)職 務適性(3)緊急対応および応急処置(4)疾病管理·健 康增進·臨床的サ一ビスという内容で構成される。

\section{【OHMSの運用】}

日本では定期健康診断・特殊健康診断などは法規 で規定されており、その要件に該当する労働者が選 定され、その法規に記された項目の検査が実施され る。OHMSでは、まず特別な職務適性が必要な業 務が明確にされ、その業務にあった項目が実施され る。その選定には、作業環境中に存在する健康に影 響するリスクを定量的に評価し、管理の優先順位を コントロールするシステム化されたリスクアセスメント 手法を用いる。この手法をEAS (Exposure Assessment Strategy)と呼び、主にIHがデータ化し リスクの評価・制御·伝達する役割を担っている。
OPはIHからEASの結果を受け、適性配置・健康 診断の実施、IHと共に教育·訓練を行い、医務の立 場からIHへリスクアセスメントの指示も役割となる。 また日本国内では法規の遵守も当然でありOPの役 割は法的にも明らかである。OHMSはグローバルに 運用されているものであり、EASや職務適性評価等 のマニュアルは非常に明確であるが、それゆえIH・ OP主体となりがちなことは否めない。実際は、OPと OHNは医務グループとして協働しているが、現時点 でOHNの職務はIH·OPほど明確化されていない。

\section{【OHN活動】}

OHMSを満たす活動の詳細な運用方法・手順は、 それを担当する主たる専門職に任されているのが現 実である。日頃の活動状況からみると、OPは産業 保健グループのチームリーダーとして多方面からの 情報をもとに、主に「判定」「決定」「指示」を行ってい る。例えば、健診実施においてもIHの情報から健診 対象職場や対象者を決定するのはOPだが、健診そ のものの企画運営、職場や受診者への連絡などは OHNが行っている。また、IHが場所·物・人の暴露な どの工学的な視点をもつに対し、OHNは従業員との 直接面談の会話から作業情報を収集したり、コーデ イネート過程で作業環境にかかわる情報を入手した り、本来の目的である人＝“健康障害を予防すべき 人”を介してのアセスメントを期待されることも多い。 また、その空口的立場からも産業保健サービスを提 供する実際場面での機動力としての期待も高い。 【まとめ】

産業保健サ一ビスの向上を考えると、サービスを受 ける側への配慮は重大な課題である。これはOHN ならではの職務といえる。OHNの役割を明確化させ るためにも、今後OPとは違う角度で、 $\mathrm{IH} \cdot \mathrm{OHN}$ 間の コラボレーションを進める必要がある。またOHN独 特の(1)First contact to Employees(従業員に接す る最初の空口)、(2)Coordinator(連携·調整役)、(3) Health Educator(個人·集団への健康教育)の役 割を認識し、OHMSで担う役割を具体的に列挙した マニュアル作りを行い共通運用できる体制を整える ことも、もう1つのOHNの役割ではないかと考える。 